\title{
Sociometric status of Theatre College students and its relation to their personal characteristics and educational activities
}

\author{
Vladimir S. Sobkin, Tatyana A. Lykova* \\ Institute for the Management of Education of the Russian Academy of Education, Moscow, Russia \\ ${ }^{\star}$ Corresponding author. E-mail: feo.tatiana@gmail.com
}

\begin{abstract}
This article presents the results of a study of sociometric status and its relation to personal characteristics and educational activities conducted on 96 first-year and 52 second-year students at the Moscow Theatre College. The sociometric study included three sets of questions combining the everyday life and communication of a student: educational activities, leadership and interpersonal communication. To determine the diagnostics of personality characteristics, Cattell's multiple-factor personality questionnaire $16 \mathrm{PF}$ was used.

The comparative analysis of the group unity sociometric index has shown that there is more mutuality in the choices dealing with interpersonal communication than in the choices dealing with professional activities. The grades that teachers give in actor training appear as a steady focus that determines the degree of leadership/reject not only in the professional but also in the social and interpersonal spheres. The high level of motivation (energy and determination) captured by Cattell's factor test Q4 is one of the most significant qualities that determines the number of choices in various spheres of student activity (mastering the profession, leadership qualities and interpersonal communication).
\end{abstract}

Keywords: sociometric status, actor's talent, personal characteristics, psychology of the actor, professional education

\section{Introduction}

Psychological research that deals with the personality and professional peculiarities of an actor typically aims at studying two primary spheres. The first sphere of research is aimed at specific physical functions such as the cogitation, will, imagination, memory and emotional spheres (Drankov, 1973; Natadze, 1972; Simonov, 1962; Tal'yan, 1966). The second research area involves personality structure and its peculiarities such as the motivational, self-construction, skills and professional orientation spheres (Galkina, 2011; Kochnev, 1983; Malevski, 1998; 
Popova, 2004; Roslyakov, 1992; Fishman-Borisov, 2005). Giving weight to the works mentioned above, we concluded that the most effective approach to studying an actor's gift would be a complex approach. This approach would combine creative skills diagnosis with analysis of personal and psycho-physiological peculiarities of an individual as well as the specific character of his or her professional activities (Groisman, 2007; Rozhdestvenskaya, 2005; Sobkin, 1984; Sobkin, Feofanova, 2012).

Activity analysis of the actor's profession is primarily found in research based on the study of art, which looks at the variety and peculiar properties of some dramatic psychotechnics and their pedagogical aspects (Chekhov, 1999; Ershov, 2010; Gracheva, 2005; Knebel, 2005; Koshevaya, 2009; Stanislavskii, 2012; Tabakov, 1986;). It is important to mention that educating an actor is "projecting activity onto the layer of its acquisition" (Davydov, 2010). Thus, it is possible to examine the structure and peculiar properties of the acting profession on a wider scale. One of the most interesting phenomena to look at, in our opinion, is the personality change of actors-to-be (students) at various steps of mastering the profession. Several of our previous works involved analyzing those personality changes (Sobkin, 1984; Sobkin, Feofanova, 2012).

Notably, the process of educating an actor is triggered by the general sociocultural context. Broadly speaking, this context determines the general path of an actor's personality formation. Of primary importance here are the plot and subject matter of a piece of fiction, which are offered to the students in the process of work.

Specific organization of the educational process involves active cooperation and participation of teachers and students in discussing up-to-date social problems, politics, details of their own lives and interpersonal conflicts. They also talk about literary works, cinema, music pieces, etc. A large part of creative exercises and tasks based on extracts of classic and modern drama is dealt with by students themselves; thus, they are expected to choose partners and organize work on their own. In this regard, intra-group relationships of actorsto-be seem to be vitally important. The peculiarities of these relations result in general productivity and success in the work, atmosphere and psychological climate of the group.

The personality traits of each student (emotionality, sociability, urge to dominate, etc.) influence the intra-group relationship in a meaningful way. In the phase of short listing during entrance examinations, a number of personality traits and accentuations play a major part (Sobkin, Feofanova, 2012). Those traits are sociability, openness, courage, high-level emotional response, conformism, and readiness to cooperate and participate in group activities. These personal peculiarities are professionally important and fundamental for a future actor. Furthermore, those qualities take a great toll on the relationships inside the group and create a unique communicative situation because an actor's education suggests constant group work and cooperation. A question arises at this point: how can a study group (usually consisting of 24 students) with similar personality traits function in an effective way? In this respect, classic socio-psychological scenarios dealing with the study of small groups are considered. Those are formal and informal lead- 
ership and the dependence of intra-group status on personality traits and success in educational activities. These aspects are discussed in this article.

\section{Method}

The research of intra-group relationships was conducted using sociometry methods among the students of the Moscow Theatre College under the direction of O. Tabakov. A total of 96 first-year students (in 2010, 2011, 2012 and 2013) and 52 sophomores (in 2010, 2011, 2012) participated in the research. The students were offered various communicative and relationship situations in which they had to note the three most preferable fellow-students for cooperation.

The situations offered to the students during the sociometric research are analyzed below. They fall into three major groups, combining the everyday life and communication of a student: educational activities, leadership and interpersonal communication.

The striking feature of an actor's education is that that he or she does not only have to study professional disciplines such as actor's skills, scenic speech, stage movement, dance and vocals but also each student must study a range of general education subjects, such as history, mathematics, and the Russian language, etc.. Moreover, these two groups of subjects differ considerably in formatting of classes, teaching methods and quantity of study hours. Professional subjects are typically taught in an informal and creative game-like manner, where a teacher-student personal contact prevails, whereas general education subjects are taught in the classic format of a school lesson. To get the overall picture of the relationship inside those two types of educational situations, we posed two major questions to the students: "What fellow-student would you most likely ask for help in preparing for a general education subject?" and "Who would you most likely practice a sketch or prepare an extract with?" The work on extracts and sketches is one of the major educational activities in the first and second years, which is why we offered it as a sociometric question.

The second important sphere of intra-group relations between actors-to-be is leadership. Two primary directions are outlined in this case. On the one hand, the role of a group monitor, who is responsible for the communication with teachers and college administration on organizational topics, is important. On the other hand, the skills of organizing and self-organizing are vital because students often receive individual tasks from teachers, performing that is only possible in small or large groups. To discover the most appropriate candidates for being a monitor, the following question was asked: "What fellow-student do you think would be the best monitor?" Analyzing the students' answers lets us learn the attitude to the present monitor and see his or her possible "competitors." The second question addresses discovering students with leadership qualities: "What fellow-students do you think have the most developed organizational skills?"

The third series of questions touch upon interpersonal communication and students' affections. We also posed two questions to the informants. The first question addresses finding out the most authoritative and valued members of the group ("Who would you ask for advice in a difficult situation?"); the second question reveals each student's level of popularity ("Who would you like to spend a day-off with?"). 


\section{Results}

\section{Sociometric index analysis among first- and second- year students of the Theatre College}

The first step of the students' sociometric peculiarities research was the analysis of sociometric indexes, which shows the level of unity and togetherness in a group. The group unity index is referred to as Iguand; the level of relationship well-being is referred to as Irw. Group unity index, showing mutuality of choices in the group, is calculated as the ratio of the sum of mutual positive elections in the group to the maximum possible number of positive elections: the higher its number, the more mutual choices were made (Moreno, 2001; Volkov, 2002). The index of relationship well-being is calculated as a ratio of the number of leaders (more than 6 choices) and preferable members (3-6 choices) to the number of neglected (1-2 choices) and rejected (no choices) members. A low level of the index means a predominance of people with lower status in the group and small number of leaders. A high level of the index is characterized by predominance of "stars" and favored members of the group (Moreno, 2001; Volkov, 2002).

The calculation of those indexes was conducted for two questions: "Who would you like to spend a day-off with?" and "Who would you most likely practice a sketch or prepare an extract with?" We chose those questions because, in our opinion, they capture two different aspects of group relationship. The question about a dayoff is aimed at finding out preferences in an informal setting, whereas the question about a sketch addresses the relationship in a professional setting. The results are shown in Table 1.

Table 1. Group unity index $\left(\mathrm{I}_{\mathrm{gu}}\right)$ and index of relationship well-being $\left(\mathrm{I}_{\mathrm{rw}}\right)$ for the questions "Who would you most likely practice a sketch or prepare an extract with?" and "Who would you like to spend a day-off with?"

\begin{tabular}{ccccc}
\hline \multirow{2}{*}{ Years } & \multicolumn{2}{c}{ Group Unity Index } & \multicolumn{2}{c}{ Index of Relationship Well-Being } \\
\cline { 2 - 5 } & A Sketch & A Day-Off & A Sketch & A Day-Off \\
\hline 1st year & 0.23 & 0.36 & 0.44 & 0.49 \\
2nd year & 0.26 & 0.46 & 0.50 & 0.57 \\
\hline
\end{tabular}

As the table suggests, the group unity index in the question about a sketch is much lower than in the question about a day-off. This result proves that mutuality in an informal setting is more frequent than in a formal one. We consider that the tendency is rooted in the fact that mutual choices in an informal setting are brought about by interpersonal affections. The nature of choices is different for a professional setting-students tend to choose most talented and "strong" peers, lowering the chance of mutuality because the number of leaders in a professional setting is low.

Despite these differences, it is worth pointing out that the index of relationship well-being is rather high for first- and second-year students in both informal and professional spheres. The index tends to grow in the second year. 


\section{Sociometric links of Theatre College's first- and second-year students}

Examination of the correlational analysis results of linking sociometric status indexes in various spheres of student's social activity is the next subject considered. Those spheres are as follows: helping in educational subjects, working on a sketch together, choosing a monitor, demonstrating organizational skills, asking for advice in a difficult situation and spending a day-off together (Figures 1 and 2).

For the sample of first-year students $(\mathrm{N}=96)$, the correlation is significant at the 0.01 level if its value is greater than 0.26 , and it is significant at the 0.05 level if its value is greater than 0.22 . For the sample of second-year students $(\mathrm{N}=52)$, the correlation is significant at the 0.01 level if its value is greater than 0.36 . Note that a rigorous statistical evaluation of the above correlation is difficult, and the results should be considered as trends.

As Figure 1 shows, the largest numbers of links are found in status position distributions on the following topics: sketch, asking for advice and organizational skills. Notably, these are interconnected and capture the similarity of the group members' status positions in demonstrating various types of social activity. It is also significant that personal authority is connected to leadership qualities ("organizational skills"), success in professional setting ("a sketch") and personal affections of the students ("a day-off").

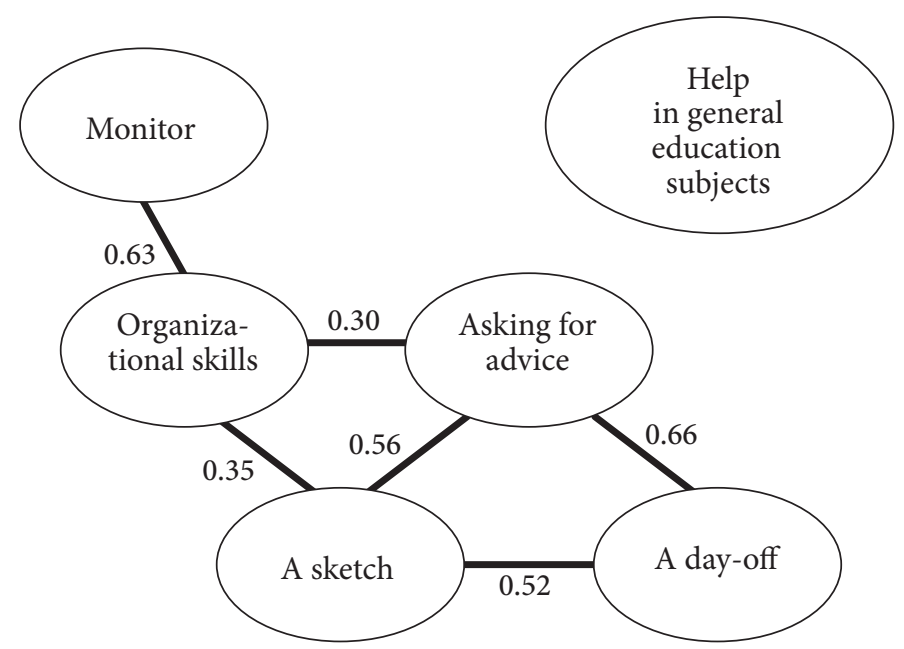

Figure 1. Constellation of significant correlations in sociometric status indexes among first-year students.

Note: a solid line shows positive links, the correlations of which are significant, $\mathrm{p}=.01$.

It is worth mentioning that the choices of the most interesting and amiable fellow-students for a "day-off" correlate with their professional appeal ("a sketch") and general authority ("asking for advice"), whereas their leadership qualities ("organizational skills") do not play a significant role in this case. Additionally, the connection between the good organizational skills of a monitor and the number of choices he or she received was confirmed. However, the results suggest that the role 
of a formal leader (monitor) is not connected to the number of choices in other areas of activity.

Moreover, it is worth mentioning that the position "help in general education subjects" does not have any significant correlations with other spheres of social activity. This fact points to the conclusion that educational activity in general subjects is neither connected to professional activity nor to personal relations.

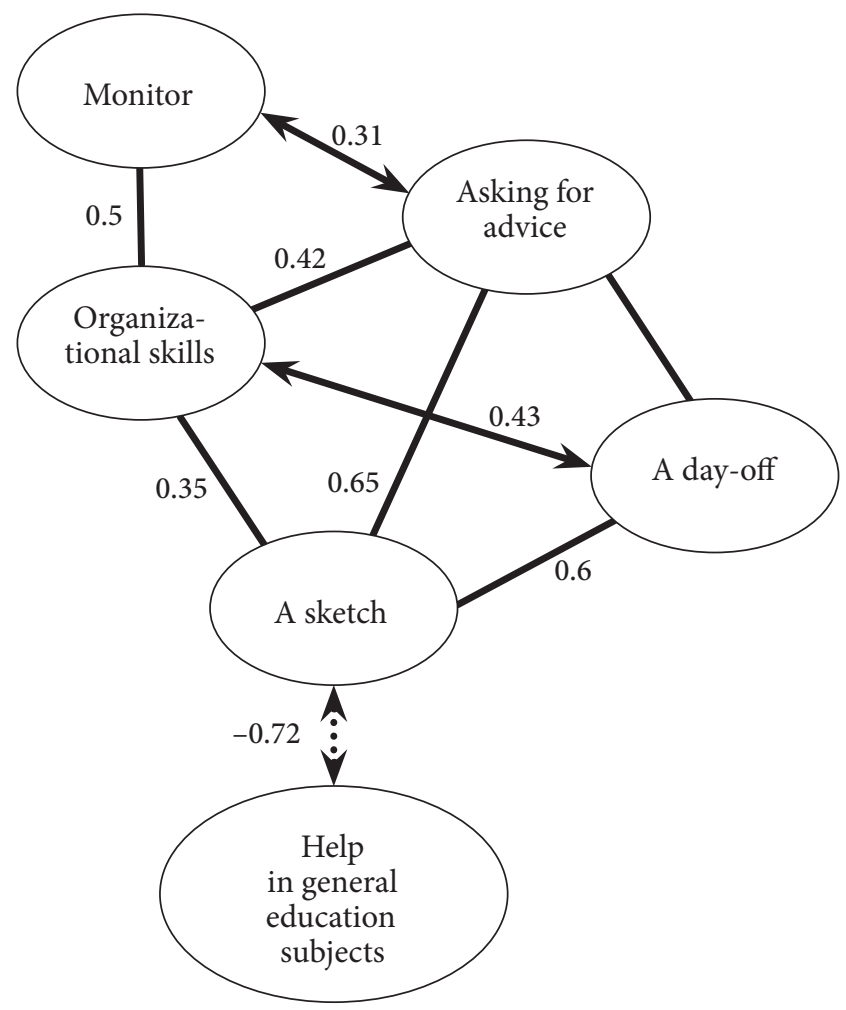

Figure 2. Constellation of significant correlations in sociometric status indexes among the second-year students.

Note: a solid line shows positive correlations; a dotted line shows negative correlations;

leader lines show new connections compared to Figure 1; the correlations are significant, $\mathrm{p}=.01$.

Figure 2 shows the constellation of correlations in sociometric status indexes for various types of activity among the second-year students. The main structure remains unchanged (closely interconnected positions of "a sketch," "a day-off," "organizational skills" and "asking for advice”). However, the students' attitude towards choosing a monitor has obviously changed. Here, the social function of a monitor is not only connected to his or her organizational qualities (as in the first year) but also correlates to a person's general authority ("asking for advice").

Another important difference addresses the appearance of a negative link between "a sketch" and "help in general educational subjects." The results for the firstyear students suggested that general subjects are treated as a parallel type of activity, not connected to either professional or informal settings. The results for the 
second-year students, however, tend to show the contradiction between mastering the profession and being good at general educational subjects. The leaders in general education subjects, as a rule, fail to become leaders in mastering the profession. Note that the set of general subjects in the college is the same as 10-11 class regular schools and are invariant in the first and second year of study.

In our opinion, the results given above should be matched to general theorems focused on the peculiarities of developmental age at the stage of transition between junior and senior school. In senior forms, leadership zones are usually differentiated, forming a complex structure where "straight A" students rarely become informal leaders of the class, whereas the most amiable and interesting fellow-students tend to have lower grades. In our case, this well-known tendency is interpreted in reference to the dynamics of changing the major type of activity at various age stages (Elkonin, 1971). Thus, educational activity (junior school age) is succeeded by communication with peers at the teenage stage. The results we received for actors-to-be, at the same time, suggest that in the case of early professional training, the developmental age tends to move in a slightly different direction. Thus, professional success (a large number of choices in "a sketch") tends to be closely connected to informal leadership among peers. This fact proves that mastering the profession is a personally important and leading type of activity, while educational activities in terms of general subjects do not seem to be that important. All of these facts support the general trend of transition into a senior school age.

\section{Connection of sociometric status to success in acting and personal qualities}

The next step in our analysis was to discover the connections between the students' sociometric status, their personal peculiarities and their grades in acting. We chose the grades in "actor training" for two primary reasons. First, they have a greater personal value to the students; second, they are most responsible for a student's expulsion (i.e., they pose a threat to becoming a member of the group).

In the course of research, a correlational analysis was conducted that portrayed the links between students' sociometric status, grades in "actor training" and indexes of Cattell's multiple-factor personality questionnaire $16 \mathrm{PF}$, which describes communicative, intellectual emotional and regulatory peculiarities of a person (Kapustina, 2001; Cattell, 1970 ). Figure 3 shows the correlational links we obtained for the first-year students.

As Figure 3 suggests, Cattell's factor Q4 (tension) is positively connected to the positions focusing on informal leadership ("asking for advice," "a dayoff”), professional success ("a sketch") and leadership qualities ("organizational skills"). It is worth mentioning that higher indexes of the factor showing a complex of the named personal characteristics become vitally important for achieving a higher status in all spheres of significant social activities among the firstyear students.

Cattell's Q1 factor (radicalism) is another significant characteristic in informal communication sphere ("a day-off", "asking for advice"). It is understood as the urge for independence, autonomy and non-recognition of authority. In this case, the symptoms of radicalism may become valuable to teenagers due to the pecu- 


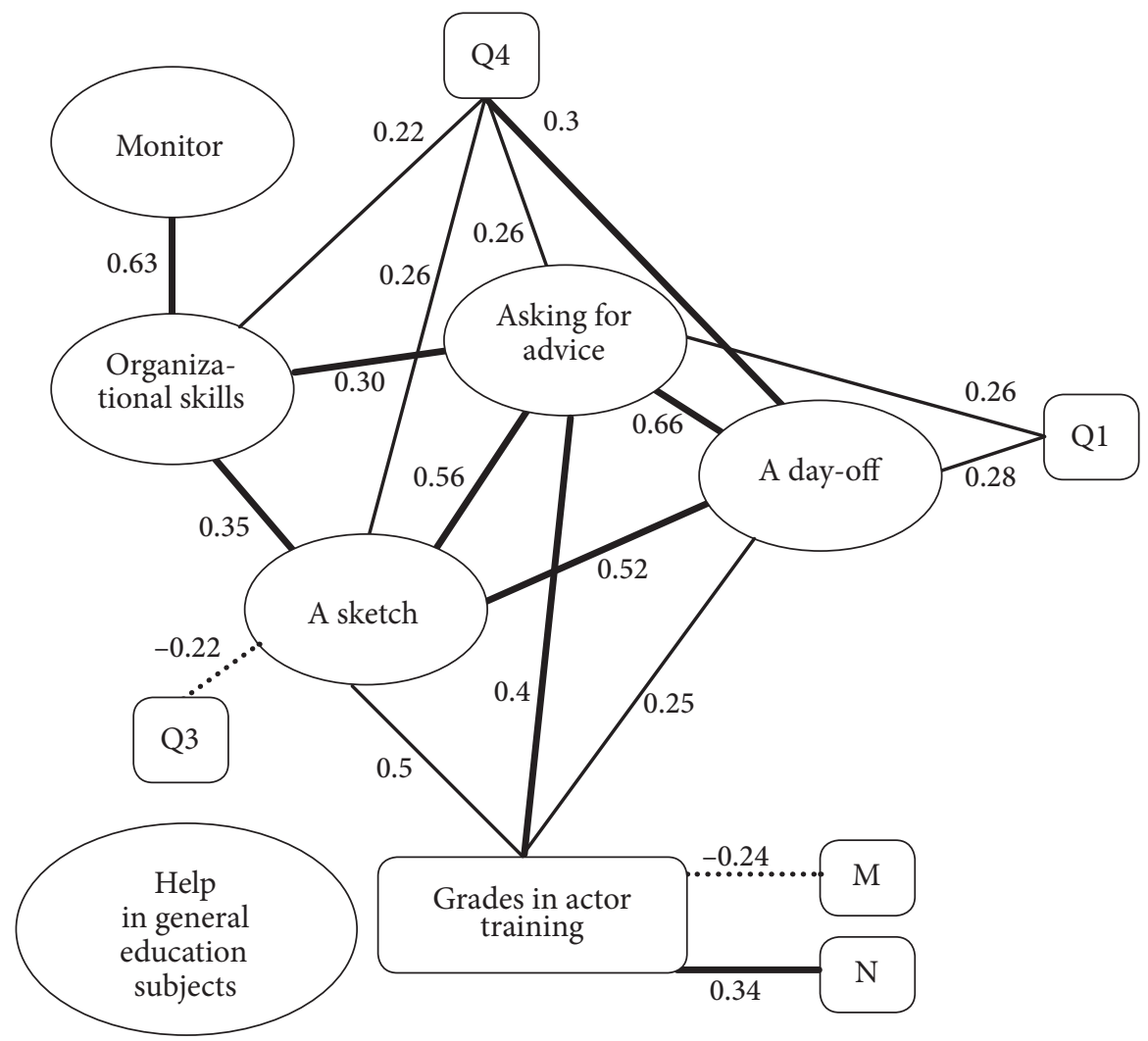

Figure 3. Constellation of significant correlations in sociometric status indexes, grades in actor training and Cattell's test factors for the first-year students.

Note: a solid line shows positive correlations; a dotted line shows negative correlations; bold lines show that the correlations are significant, $\mathrm{p}=.01$; narrow lines show that the correlations are significant, $\mathrm{p}=.05$.

liarities of their developmental age because young people strive to find their place under the sun and their own ideologies (Erikson, 2006).

The number of choices in a key position, "a sketch", is negatively correlated to higher indexes of Q3 factor (self-control), which suggests that leaders in this sphere possess peculiar personality traits, such as impulsivity, lack of discipline and moodiness. As a rule, those who possess these qualities do not tend to have a leader's role in communication and, for the most part, remain passive but simultaneously emotionally free. However, the complex of the qualities addressed as low self-control may become an important characteristic in this stage of mastering the profession. Those qualities let students be sensible to the way others estimate them. This is important not only in a "student-teacher" relationship but also in the course of collective creative work where a student reacts on his peers' level of control.

The grades in actor-training are positively connected to the positions of "a dayoff," "asking for advice" and "a sketch". Thus, we can see that the grades teachers give do not only influence the professional success of a student ("a sketch") but also influence their interpersonal communication ("asking for advice," "a day-off”). 
Furthermore, higher grades in actor training have positive correlations with Cattell's factor $\mathrm{N}$ (diplomacy) and negative correlations with factor M (dreaminess). The positive pole of factor $\mathrm{N}$ captures such traits of character as breeding, cunningness, insight and caution. Cattell (1970) defined this as "Machiavelli's pole," which characterizes the ability to reflect another person's position during interpersonal communication. Lower diplomacy indexes suggest immediatism, natural behavior, openness and simplicity, whereas higher diplomacy indexes of insight and social sensitivity allow students to understand their teachers' instructions more precisely and more clearly perceive their characters' emotions.

As to factor $\mathrm{M}$, people with higher $\mathrm{M}$ indexes tend to have a richer imagination and a more artistic perception of the world. On an opposite pole, there are realityoriented people who have practical minds. This tendency confirms our previous results (Sobkin, Feofanova, 2012) and could be interpreted as follows: in modern setting higher indexes of factor $\mathrm{M}$ (dreaminess) are manifested not only in the form of rich and well-developed imagination, but mostly point to a person's absorption into his inner illusions and patterns. The fact is also mentioned by the authors (Kapustina, 2001; Cattell, 1970). It usually stands in the way of students' perception of criticism and teacher's remarks as well as changing the direction of his or her creative work etc. (Sobkin, Feofanova, 2012).

Similar correlational analysis was performed using the results for the secondyear students. The analysis found a number of tendencies. During the first year of study, the central personality determining leadership in the fields of professional success and interpersonal relationships was Cattell's factor Q4 (tension); in the second year, it was not displayed as an important characteristic in various social positions. Furthermore, the significance of personality traits in sociometric status is declined in general: The correlations between sociometric indexes and Cattell's factors are nearly absent.

The grades for actor training in the second year, as in the first year, tend to be connected to a higher student's status in a professional setting ("a sketch") and in the sphere of interpersonal relations ("asking for advice," "a day-off”). This fact suggests that a mark given by a teacher is important not only for the professional status of a student but also for the sphere of his or her interpersonal relations in both the first and second years.

\section{Conclusion}

The results of the research lead us to conclude as follows:

1. The comparative analysis of the relationship well-being index among Moscow Theatre College's first- and second-year students has shown that a friendly atmosphere and a healthy psychological climate are typical in both professional and interpersonal settings.

2. The comparative analysis of the group unity sociometric index has shown that there is more mutuality in the choices dealing with interpersonal communication ("Who would you like to spend a day-off with?") than in the choices dealing with professional activities ("Who would you most likely practice a sketch or prepare an extract with?"). 
3. The correlational analysis has discovered a strong connection between the status positions inside the students' study groups in various spheres of social activity: mastering the profession, personal authority, organizational skills, and interpersonal relations. The complex of these connections takes place in both the first and second years of study.

4. The research has discovered a sticking change in the students' attitude towards a formal leader (monitor) by the end of the second year of study. Estimating his or her authority is influenced not only by organizational skills but also by personal authority among peers.

5. In the course of study, there appears to be a considerable difference in the students' attitude towards professional disciplines and general education subjects. Professional activities are treated as main and personally important, whereas general education activities are paid less attention to. Additionally, a student's success in the professional sphere is closely connected to his or her personal authority inside the group, leadership qualities and general appeal.

6. The grades that teachers give in actor training appear as a steady focus, which determines the degree of leadership/reject not only in the professional but also in the social and interpersonal spheres.

7. High level of motivation (energy and determination) captured by Cattell's factor test is one of the most significant qualities that determines the number of choices in various spheres of students' activity (mastering the profession, leadership qualities, and interpersonal communication).

\section{Acknowledgments}

This article constitutes a part of a scientific project regarding actor's gift. It was prepared within the framework of a cooperation contract between Federal state budgetary scientific institution Institute of education management Russian Academy of education and State Budgetary Educational Institution Of Secondary Professional Education Moscow Theatre College. The authors thank People's Artist of the USSR Oleg P. Tabakov for supporting the project.

\section{References}

Benesh, N. L. (2007). Psikhologicheskie mekhanizmy empatii v akterskoi psikhotekhnike [Psychological mechanisms of empathy in the actor's psychotechnics] (Doctoral dissertation). Russia, Khabarovsk: Far Eastern State University of Means of Communication.

Cattell, R. B., Eber, H. W., \& Tatsuoka, M. M. (1970). Handbook for the Sixteen Personality Factor Questionnaire (16 PF). Champaign, IL: Institute for Personality and Ability Testing.

Chekhov, M. A. (1999). Ob iskusstve aktera [About the art of the actor]. Moscow: Iskusstvo. (Original work published 1968).

Davydov, V. V. (1996). Teoriya razvivayushchego obucheniya [The theory of developmental education]. Moscow: INTOR.

Drankov, V. L. (1973).O prirode khudozhestvennogo talanta [On the nature of artistic talent]. (Doctoral dissertation). Leningrad: Zhdanov Leningrad State University. 
Elkonin, D. B. (1971). K problem periodizatsii psikhicheskogo razvitiya v detskomvozraste [To the problem of periodization of mental development in childhood].Voprosy psihologii [Issues in Psychology], 4, 6-20.

Erikson, E. (2006). Identichnost' yunost' ikrizis [Identity: youth and crisis]. Moscow: Flinta.

Ershov, P. M. (2010). Rezhissura kak prakticheskaya psikhologiya [Directing as practical psychology]. Moscow: Mir iskusstva.

Fishman-Borisov, M. B. (2005). Stanovlenie Ya-kontseptsii v sisteme professional'nogo masterstva budushchego aktera [The formation of self-concept in the system of professional skills of the future actor]. (Doctoral dissertation). Moscow: Shchukin Theatre Institute.

Galkina, Yu. I. (2011). Psikhologicheskie determinant lichnostno-professional'nogo stanovleniya budushchikh akterov [Psychological determinants of personal and professional development of future actors]. (Doctoral dissertation). Moscow: Russian University of People's Friendship.

Gracheva, L. V. (2005). Psikhotekhnika aktera v protsesse obucheniya v teatral'noi shkole: Teoriya I praktika [Psychotechnics actor in training at drama school: Theory and practice]. (Doctoral dissertation). Saint Petersburg: Saint Petersburg State Theatre Arts Academy.

Groisman, A. L. (2007). Psikhologia uspeshnosti professional'nogo obucheniya I tvorcheskoi deyatel'nosti aktera [The psychology of successful professional learning and creative work of the actor]. Moscow: Kogito-Tsentr.

Kapustina, A. N. (2001). Mnogofaktornaya lichnostnaya metodika R. Kettella [Multifactor personal questionnaire by R. Cattell]. Saint Petersburg: Rech.

Knebel, M. O. (2005). Poeziya pedagogiki. O deistvennom analize p'esy i roli [Poetry pedagogy. Effective analysis of the play and the role]. Moscow: GITIS.

Kochnev V. I. (1983). K problem izucheniya akterskikh sposobnostei [To the problem of studying acting abilities].Voprosy psikhologii [Questions of psychology], 1, 108-114.

Koshevaya E. A. (2009). Teatral'naya shkola I problema razvitiya akterskikh sposobnostei [Theatre school and the problem of development of acting skills] (Doctoral dissertation). Saint Petersburg: Saint Petersburg State Theatre Arts Academy.

Malevskii, E. V. (1998). Psikhologicheskie kharakteristiki lichnosti v obuchenii aktera verbal'nomu rolevomu povedeniyu [Psychological characteristics of a person in training the actor's verbal role behavior]. (Doctoral dissertation). Moscow: Institute for Issues of Consciousness.

Moreno, Ya. L. (2001). Sotsiometriya: Eksperimental'nyi metod i nauka ob obshchestve [Sociometry: Experimental method and the science of society]. Moscow: Akademicheskii prospekt.

Natadze, R. G. (1972). Voobrazhenie kak factor povedeniya [Imagination as a factor in behavior.]. Tbilisi: Metsniereba.

Pankratov, V. N. (1992). Igrovaya priroda akterskogo tvorchestva kak problema teatral'noi pedagogiki [The playful nature of the actor's creativity as a problem of theatrical pedagogy]. (Doctoral dissertation). Moscow: Cherkasova Saint Petersburg Institute of Theatre, Music and Cinematography.

Popova, Yu. I. (2004). Perevoploshchenie kak regulyator ya-kontseptsii [Reincarnation as a regulator of self-concept]. (Doctoral dissertation). Russia, Krasnodar: Kuban State University.

Roslyakov, A. F. (1992). Motivatsionnye osobennosti lichnosti i professional'noi deyatel'nosti studenta-aktera [Motivational personality characteristics and professional activities of the student-actor]. (Doctoral dissertation). Moscow: Moscow Pedagogical State University

Rozhdestvenskaya, N. V. (2005). Diagnostika akterskikh sposobnostei [Diagnostics acting abilities]. Saint Petersburg: Rech.

Simonov, P. V. (1962). Metod K.S. Stanislavskogo i fiziologiya emotsii [The method of K. S. Stanislavsky and physiology of emotions]. Moscow: AN SSSR. 
Sobkin, V. S. (1984). Opyt issledovaniya lichnostnyh harakteristik studentov-akterov [Experience of research in personal characteristics of the student-actors]. In Psikhologo-pedagogicheskie aspekty obucheniya studentov tvorcheskikh vuzov [Psychological and pedagogical aspects of teaching art school students]. (pp. 22-37). Moscow: GITIS.

Sobkin, V. S., \& Feofanova, T. A. (2012). K voprosu o diagnostike akterskoi odarennosti: sotsial'no-psikhologicheskie aspekty [To the question about the diagnosis of acting talent: socio-psychological aspects]. Trudy po sotsiologii obrazovaniya [Works on the Sociology of Education], 28, 217-236.

Sobkin, V. S., \& Feofanova, T. A. (2012). Lichnostnye osobennosti studentov-akterov raznykh pokolenii: invariantnost' i izmenchivost' [Personal characteristics of a student-actors of various generations: invariance and variability]. Voprosy psihologii [Issues in Psychology], 4, 32-47.

Stanislavskii, K. S. (2012). Rabota aktera nad soboi v tvorcheskom protsesse perezhivaniya [The actor's work on himself in the creative process of experiencing]. Moscow: Azbuka. (Original work published 1938)

Tabakov, O. P. (1986). Moi opyt diagnostiki i razvitiya akterskoi odarennosti [My experience in the diagnosis and development of acting talent]. In Diagnostika i razvitie akterskoi odarennosti [Diagnosis and development of acting talent]. (pp. 55-65). Leningrad: LGITMIK.

Talyan, L. Sh. (1966). Nekotorye osobennosti psikhologii aktera $v$ tvorcheskom protsesse [Some features of the psychology of the actor in the creative process]. (Doctoral dissertation). Armenia, Erevan: Yerevan State University.

Volkov, I. P. (2002). Sotsiometricheskie metody v sotsial'no-psikhologicheskikh issledovaniyakh [Sociometric methods in social psychological research.]. Saint Petersburg: Saint Petersburg University Press.

Original manuscript received April 01, 2015 Revised manuscript accepted September 14, 2015

First published online December 30, 2015 